\title{
IMPLEMENTASI SISTEMATIKA FILSAFAT BAGI PENGEMBANGAN KURIKULUM PENDIDIKAN KRISTEN
}

\author{
Dyulius Thomas Bilo \\ Sekolah Tinggi Teologi Injili Arastamar (SETIA) Jakarta \\ greatshine@sttsetia.ac.id
}

\section{ABSTRAK}

Tulisan ini terdiri dari beberapa rumusan masalah yaitu: (1) bagaimana tinjauan metafisika bagi pengembangan kurikulum pendidikan Kristen, (2) bagaimana tinjauan epistemologi bagi pengembangan kurikulum pendidikan Kristen, (3) bagaimana tinjauan aksiologi bagi pengembangan kurikulum pendidikan Kristen. Tujuan penelitian ini adalah: (1) menjelaskan bagaimana tinjauan metafisika bagi pengembangan kurikulum pendidikan Kristen, (2) menjelaskan bagaimana tinjauan epistemologi bagi pengembangan kurikulum pendidikan Kristen, (3) menjelaskan bagaimana tinjauan aksiologi bagi pengembangan kurikulum pendidikan Kristen. Hipotesis penelitian ini adalah patut diduga sistematika filsafat dapat diimplementasikan dalam pengembangan kurikulum pendidikan Kristen. Hasil penelitian berdasarkan rumusan masalah pertama hasilnya adalah telah dijelaskan tinjauan metafisika bagi pengembangan kurikulum pendidikan Kristen. Rumusan masalah kedua hasilnya bahwa telah dijelaskan tinjauan epistemologi bagi pengembangan kurikulum pendidikan Kristen. Rumusan masalah ketiga hasilnya adalah telah dijelaskan tinjauan aksiologi bagi pengembangan kurikulum pendidikan Kristen. Berdasarkan hipotesis yang diajukan ternyata ditemukan bahwa sistematika filsafat dapat diimplementasikan dalam pengembangan kurikulum pendidikan Kristen. Dari hasil penelitian ini disarankan dan direkomendasi bahwa setiap pelaku pendidikan Kristen perlu mengimplementasikan sistematika filsafat dalam pengembangan kurikulum pendidikan Kristen sehingga metafisika, epistemologi dan aksiologi pendidikan Kristen dapat diwujudkan dalam pengajaran dan kehidupan para pendidik Kristen sehari-hari.

\section{Pendahuluan}

Filsafat mendorong seseorang berpikir radikal, sistematis, dan universal terhadap segala sesuatu. Maka yang menjadi objek dari filsafat adalah segala sesuatu. Karena filsafat mendorong seseorang untuk berpikir kritis dan sistematis terhadap sesuatu, maka setiap manusia perlu mensistematisasi dan mengklasifikasi segala sesuatu tersebut.

Imanuel Kant seorang filsuf dari Jerman mengajukan empat pokok pertanyaan yang harus dijawab oleh filsafat, yaitu: (1) was darf ich hoffen?: Apa yang boleh saya harapkan?. (2) was kann ich wissen?: Apa yang dapat saya ketahui?. (3) was soll ich tun?: Apa yang harus saya perbuat? (4) was ist der mench?: Apakah manusia itu?. Menurut Kant, pertanyaan pertama dapat dijawab oleh metafisika, pertanyaan kedua dijawab oleh epistemologi, pertanyaan ketiga dijawab oleh etika, dan pertanyaan keempat dijawab oleh antropologi. ${ }^{1}$ Butler (1957) yang dikutip Uyoh Sadulloh mengemukakan beberapa persoalan yang dibahas dalam filsafat, yaitu: (a) Metafisika,

\footnotetext{
${ }^{1}$ Uyoh Sadulloh, Pengantanr Filsafat Pendidikan (Bandung: Alfabeta, 2008), 27
} 
membahas: Teologi, kosmologi, dan antropologi. (b) Epistemologi, membahas: Hakikat pengetahuan, sumber pengetahuan dan metode pengetahuan. (c) Aksiologi, membahas: etika dan estetika. ${ }^{2}$

Ketiga persoalan yang dibahas dalam filsafat ini, menjadi pokok dan alur berpikir sistematis untuk mengurai segala sesuatu yang dapat menimbulkan keingintahuan dan manfaat bagi manusia. Oleh karena itu secara umum ketiga hal itu menjadi sistematika filsafat yang dibangun dari tiga tiang utama yaitu metafisika, epistemologi dan aksiologi.

\section{Pembahasan}

\section{Tinjauan Metafisika bagi Pengembangan Kurikulum Pendidikan Kristen}

Secara etimologi, metafisika berasal dari bahasa Yunani Kuno yang terdiri dari dua kata, "meta" dan "fisika". Meta berarti sesudah, di belakang, atau melampaui, dan fisika berarti alam nyata. ${ }^{3}$ Jadi istilah metafisika (metaphysics) berarti "melampaui fisiknya" (beyond physics). Metafisika berkaitan dengan sifat-sifat dari hakikat "sesuatu yang benar-benar nyata". Pertanyaan utama metafisika adalah "what is the ultimate reality?". Metafisika akan selalu berkaitan dengan spekulasi keberadaan alam dan makna dari suatu realitas. Kajian metafisika dibagi dalam empat cabang disiplin ilmu yaitu: teologi, kosmologi, antropologi dan ontologi.

Aspek teologi mencakup studi religius yang berkaitan dengan Tuhan. Beberapa persamaan sentral berbicara teologis yaitu: Apakah Tuhan itu ada?, bagaimana sifat-sfat Tuhan?, apakah Tuhan itu hanya ada satu atau lebih dari satu?, jika Tuhan itu baik dan berkuasa, bagaimana mungkin kejahatan itu ada, bagaimana tentang keberadaan rohroh malaikat, dan setan?. Akibatnya manusia terpecah dalam berbagai kelompok dalam cara dan keyakinannya untuk menjawab pertanyaan tersebut. Kelompok Atheis menyatakan Tuhan tidak ada. Kaum Agnostik meragukan keberadaan Tuhan dan tidak dapat menyatakan apakah Tuhan itu ada atau tidak. Kaum Panteis menyatakan, Tuhan dan alam semesta identik "segalanya adalah Tuhan dan Tuhan adalah segalanya". Kaum Diesme menyatakan bahwa Tuhan menciptakan hukum alam dan moral, tetapi Tuhan memisahkan keberadaan-Nya karena tidak tertarik pada manusia dan alam fisik. Politeisme menyatakan bahwa ada sejumlah Tuhan. Sedangkan Monoteisme menyatakan, hanya ada satu Tuhan. Pandangan Kristen dalam metafisika menyangkut dua lapisan (Theistic view of methaphysics), yaitu: (1) Created universe, dimana ciptaan yang terbatas menempati ruang, tergantung dan tidak tetap; (2) Uncreated being of God, yaitu tidak terbatas, kekal, berada dengan sendirinya, self-sufficient, dan tidak diciptakan. ${ }^{4}$

Pazmino menjelaskan bahwa teologi memberikan kontribusi khusus ketika menjawab pertanyaan-pertanyaan berkenaan dengan otoritas, manusia dan tujuan serta implikasinya terhadap pertanyaan-pertanyaan terkait struktur, implementasi dan evaluasi. Secara spesifik Teologi Injili menekankan otoritas kitab suci yang berfungsi sebagai dasar bagi semua pertanyaan lainnya. Teologi juga memberikan kontribusi dalam rangka memahami natur manusia sebagai ciptaan Tuhan dan karenanya bertanggung jawab kepada-Nya. Dalam hal tujuan umum dan khusus, teologi memberikan panduan yang berfungsi untuk mengarahkan semua upaya yang dilakukan manusia, termasuk pendidikan. Oleh karena itu, teologi berfungsi sebagai fondasi bagi filosofi pendidikan Kristen secara menyeluruh. ${ }^{5}$

\footnotetext{
${ }^{2}$ Sadulloh, Pengantar Filsafat Pendidikan, 28

${ }^{3}$ Sadulloh, Pengantanr Filsafat Pendidikan, 28

${ }^{4}$ Khoe Yao Tung, Filsafat Pendidikan Kristen (Yogyakarta: Andi, 2013), 7

${ }^{5}$ Robert W. Pazmino, Fondasi Pendidikan Kristen (Jakarta: BPK. Gunung Mulia, 2012), 123
} 
Menurut Jonihot Simanjuntak bahwa sesuatu yang menentukan filsafat pendidikan seseorang guru adalah seperangkat keyakinan yang dimiliki dan berhubungan kuat dengan perilaku guru, yaitu: keyakinan mengenai pengajaran dan pembelajaran, siswa, pengetahuan, dan hal yang perlu diketahui. Hal-hal tersebut akan mewarnai sikap perilakunya dalam mengelolah belajar mengajar. Selain itu, pemahaman theologi akan menjauhkan guru pendidikan Agama Kristen dari perbuatan meraba-raba, mencobacoba tanpa rencana dalam menyelesaikan masalah pendidikan. Maka di sini, theologi sebagai penerang kuat bagaimana seharusnya seorang guru Pendidikan Agama Kristen bersikap, baik terhadap dirinya maupn siswa sehingga siswa dibawa pola hidup yang benar sesuai kebenaran yang alkitabiah yang diajarkan. ${ }^{6}$

Aspek kosmologi mencakup studi mengenai teori-teori tentang asal usul dari sesuatu, sifat dan perkembangan dari alam semesta sebagai sistem yang teratur. Kosmologi menyangkut keterkaitan hukum-hukum semesta dalam massa, ruang dan waktu. Bagaimana awal alam semesta terbentuk dan berkembang? Adakah tujuan hendak dicapai dari pembentukan alam semesta?, pertanyaan tentang tujuan merupakan jawaban dalam aspek teleologis (tujuan). Iman Kristen memandang berakhirnya dunia dengan kedatangan Yesus Kristus untuk kedua kalinya merupakan aspek yang menjawab tujuan yaitu aspek teteleologis. ${ }^{7}$

Dunia dan sekitarnya menjadi bagian penting dari apa yang diciptakan Tuhan untuk kehidupan dan kesejahteraan manusia. Pazmino mengisyaratkan bahwa studi kosmologi memunculkan pertanyaan tentang natur kosmos, alam semesta, dan dunia. Dunia dipahami sebagai suatu jejaring dari kesalingbergantungan yang disebabkan oleh ciptaan dan pemeliharaan Allah yang terus menerus. Isu-isu ini menarik pemikiran Raja Daud yang mengatakan "Tuhanlah yang empunya bumi serta segala isinya, dan dunia serta yang diam di dalamnya. Sebab Dialah yang mendasarkannya di atas lautan dan menegakkannya di atas sungai-sungai (Mzm. 24:1-2). ${ }^{8}$

Apabila dikaitkan dengan dunia pendidikan, maka muncullah pertanyaanpertanyaan yang berkenaan dengan penatalayanan yang benar di bumi dan di lingkungannya. Penatalayanan ini juga menyangkut ke bidang-bidang pendidikan khususnya mengenai kurikulum dan pengembangannya. Lapangan pendidikan dan aspek-aspeknya merupakan kosmos yang dapat dijadikan lahan bagi manusia untuk mengeksplorasi kemampuannya dalam bidang pendidikan. Manusia harus ingat bahwa kosmos yang disediakan Allah ini harus dijaga dan dibagikan. Howard Snyder menyarankan sebuah model bagi gereja yang hadir di dalam dunia dengan gagasan ekologi kerajaan yang menggambarkan kepekaan terhadap isu-isu kosmologis yang mengandung implikasi penting bagi pendidikan Kristen. ${ }^{9}$

Lebih hal praktis pendidikan, Jonihot mengatakan bahwa metafisika merupakan bagian filsafat yang mempelajari masalah hakikat: hakikat dunia dan hakikat manusia, termasuk di dalamnya hakikat anak. Kosmologi secara praktis menjadi persoalah utama dalam pendidikan karena anak bergaul dengan dunia sekitarnya, ia memiliki dorongan kuat untuk memahami segala sesuatu yang ada. Memahami filsafat secara emplisit diperlukan untuk mengetahui tujuan pendidikan. Seorang guru seharusnya tidak hanya tahu hakikat dunia tempat ia tinggal, tetapi harus tahu manusia, khususnya hakikat anak. Hakikat manusia adalah makhluk jasmani-rohani, makhluk individual-sosial, bebas

\footnotetext{
${ }^{6}$ Jonihot Simanjuntak, Filsafat Pendidikan dan Pendidikan Kristen (Yogyakarta: Andi, 2013), 99

${ }^{7}$ Tung, Filsafat Pendidikan Kristen, 6

${ }^{8}$ Pazmino, Fondasi Pendidikan Kristen, 125

${ }^{9}$ Pazmino, Fondasi Pendidikan Kristen, 126
} 
dan menyejarah. Hal ini sangat penting sehingga pendidik tahu cara memperlakukan anak didik dan tujuan pendidikan. ${ }^{10}$

Aspek antropologi sangat berkaitan dengan studi tentang manusia. Hubungan dengan pendidikan, antropologi menyangkut manusia sebagai subjek dan objek dalam proses pembelajaran. Kalau kita menelusuri Matius 22:37-40 dan dalam kitab Injil lainnya yang didalamnya menyangkut mengasihi Allah dan sesama manusia dengan segenap hati, segenap jiwa, segenap akal budi, dan segenap kekuatan, maka pertanyaan antropologinya: apa hubungan antara akal budi dan tubuh?, bagaimana interaksinya? Apakah akal budi lebih fundamental dibandingkan tubuh? Bagaimana status moral kemanusiaan? Apakah orang dilahirkan baik, jahat atau netral secara moral, dan sejauhmana individu itu terbebas?

Penjelasn Pazmino menarik bahwa Antropologi pada dasarnya berpusat pada natur manusia. Dari sudut pandang kristiani, manusia dipandang sebagai ciptaan Allah yang diciptakan segambar dan serupa dengan Allah dan karenanya mempunyai tanggung jawab dan kewajiban sebagai pembawa gambar Allah. Namun disisi lain bahwa manusia juga dipandang sebagai makhluk yang sudah jatuh dan tercemar dosa yang membawa konsekuensi terhadap seluruh lapisan kehidupan manusia baik secara personal maupun secara korporat. Implikasi pendidikan yang muncul dari aspek ciptaan dan kejatuhan memengaruhi pendidikan. Misalnya, orang-orang yang terus didorong untuk bertindak secara bertannggung jawab dalam semua interaksi dan relasi mereka lewat pendidikan, agar mereka memuliakan Allah Pencipta. Di sisi lain manusia juga didorong untuk menyatakan natur kreatif yang sudah Allah berikan kepada mereka. Pada diri nara didik, dengan mengenal natur manusia sebagai makhluk ciptaan Allah para peserta didik bisa didorong untuk menjadi partisipan aktif dalam pendidikan mereka serta berinteraksi dengan dunia sebagai fokus mereka.

Oleh karena itu studi antropologi memaksa kita untuk mempertimbangkan hal yang tidak sekadar soal individu dan ruang kelas yang terisolasi. Manusia juga perlu dipandang dalam hubungannya dengan masyarakat dan budaya. Manusia juga perlu dipandang dalam hubungannya dengan sejarah yang bersifat pribadi maupun korporat. Hal ini tentunya mendorong para pendidik Kristen untuk mempertimbangkan pertanyaan-pertanyaan yang bersifat antar-pribadi, antar-kelompok, antar-budaya, dan antar masyarakat. ${ }^{11}$

Aspek ontologi merupakan ilmu yang mempelajari sifat dari eksistensi (keberadaan) atau maknanya bagi apapun yang ada. Fungsi ontologi adalah menentukan hal yang kita maksudkan ketika kita menyatakan sesuatu itu dengan mendefinisikannya. Ada beberapa pertanyaan sentral dalam ontologi seperti: Ada beberapa pertanyaan sentral dalam ontologi seperti: apakah hakikat dasar didapati pada energi roh atau spritual? Apakah hakikat itu tersusun dari satu unsur saja (roh atau fisik) atau terdiri dari dua unsur tersebut? Apakah hakikat sudah teratur dan mengikuti aturan dengan sendirinya? ${ }^{12}$

Demikian pula ontologi mempertanyakan tentang keberadaan dan kehidupan. Pazmino menghubungkan hal ontologi dengan keberadaan Paulaus di Atena. Paulus berkata-kata, kepada orang-orang Atena bahwa di dalam Allah "kita hidup, kita bergerak, kita ada" (Kis. 17:28). Cara pandang alkitabiah menyatakan bahwa keberadaan Allah adalah yang utama, di mana keberadaan manusia bersifat sekunder karena kita berasal dari Dia. Ini merupakan konsekuensi natural dari penciptaan. Tujuan keberadaan kita adalah memuliakan Allah dan menikmati Dia untuk selama-lamanya. Orang Kristen akan memenuhi tujuan ini dengan cara terlibat secara aktif dalam dunia,

\footnotetext{
${ }^{10}$ Simanjuntak, Filsafat Pendidikan dan Pendidikan Kristen, 97

${ }^{11}$ Pazmino, Fondasi Pendidikan Kristen, 124

${ }^{12}$ Tung, Filsafat Pendidikan Kristen, 8
} 
tetapi tidak berasal dari dunia. Ini semua hanya dimungkinkan lewat karya penebusan Allah. Orang Kristen hadir di dunia sebagai orang buangan dan musafir, sebagai anggota kerajaan Allah menjalani hidup ini untuk mengalami pembaruan dan menyatakan buah penebusan dalam Yesus Kristus. Orang Kristen dipanggil untuk mengerjakan keselamatan mereka dengan takut dan gentar sementara tetap menyadari pekerjaan Allah dalam diri mereka dalam rangka menggenapi rencana-Nya (Flp. 2:12-13). Sebagai ciptaan baru dalam Kristus, orang Kristen mengemban tugas sebagai duta Kristus, yang membawa berita pendamaian (2 Kor. 17-21). Orang Kristen perlu setiap hari dipenuhi Roh Kudus untuk mencapai tujuan Allah. Hal ini merupakan jawaban-jawaban terhadap pertanyaan ontologis terhadap suatu keberadaan dan kehidupan. ${ }^{13}$

Dalam pengembangan kurikulum, implikasi metafisika mendorong para pelaku pendidikan untuk menentukan jenis-jenis kurikulum yang dapat diterapkan secara literal dan tersirat pengajaran untuk mencapai tujuan pendidikan yang telah ditetapkan. Arah pendidikan sangat dipengaruhi oleh kurikulum yang aktual dan kurikulum yang hidden (tersembunyi).

\section{Tinjauan Epistemologi bagi Pengembangan Kurikulum Pendidikan Kristen}

Suatu pernyataan mengatakan "De omnibus dubitandum" segala sesuatu harus diragukan desak sang filsuf Rene Descartes. Namun segala yang ada dalam hidup ini dimulai dengan meragukan sesuatu. Makanya kalau menemukan kebenaran berarti sudah tidak ada lagi keraguan. Kebenaran adalah pernyataan tanpa ragu. ${ }^{14}$

Socrates menggambarkan akal merupakan segalanya, dan merupakan pokok serta satu-memperoleh ilmu pengetahuan. Epistemologi, biasanya didefinisikan sebagai cabang ilmu filsafat yang membahas ilmu pengetahuan secara menyeluruh dan mendasar. Epistemologi adalah theory of knowledge. Epistemologi berbicara tentang sumber-sumber ilmu dan bagaimana manusia bisa meraih ilmu. Bagi manusia, knowledge atau ilmu pengetahuan merupakan sesuatu yang sangat mendasar dalam kehidupan manusia. ${ }^{15}$

Secara harafiah istilah epistemologi berasal dari bahasa Yunani Kuno, dengan asal kata "episteme" dan "logos". Episteme berarti pengetahuan, dan logos berarti teori. Secara etimologi epistemologi berarti teori pengetahuan. Dengan demikian epistemologi berkaitan dengan pertanyaan "what is the nature of knowledge?" Epistemologi menjawab pertanyaan-pertanyaan tentang kebenaran dan pengetahuan. Maka epistemologi merupakan cabang dari filsafat yang mempelajari sifat, sumber, dan validitas dari pengetahuan. Pertanyaan tentang epistemologi bertujuan menjawab kebenaran, berkaitan dengan apakah kebenaran itu sesuatu yang relatif atau mutlak, apakah ilmu pengetahuan itu bersifat subjektif atau objektif, apakah ada kebenaran di luar dari pengalaman manusia. Dalam catatan Khoe Yao Tung terdapat beberapa kebenaran:

a. Absolute truth, kebenaran mutlak, objektif, kekal, dan universal tidak bergantung pada situasi.

b. Relative truth, kebenaran yang tergantung situasi, relatif.

c. Skepticism, meyakini mereka dapat mencari kebenaran, keraguan dan tidak berusah mencarinya, atau sia-sia bila mencobanya.

\footnotetext{
${ }^{13}$ Pazmino, Fondasi Pendidikan Kristen, 125

${ }^{14}$ Jujun S. Suriasumantri, Filsafat Ilmu Sebuah Pengantar Populer (Jakarta: Pustaka Sinar Harapan,2009), 50

${ }^{15}$ Ardian Hisaini, Filsafat Ilmu: Perspektif Barat dan Islam (Jakarta: Gema Insani, 2013), 27
} 
IMPLEMENTASI SISTEMATIKA FILSAFAT ... (Dyulius Thomas Bilo)

d. Agnoticisme, meyakini ada kemungkinan akan kebenaran tetapi tidak mengetahui kebenaran dengan pasti.

e. Recipient truth, kebenaran seseorang karena pengaruh dari masyarakat tertentu

f. Participant knowledge, kebenaran yang didapatkan dengan menyertakan partisipasi untunk mendapatkan kebenarannya.

g. Architecture truth, mencari dan menyusun kebenaran sendiri

h. A priori knowledge-deductive truth/top-down, kebenaran yang dimulai dari dengan prinsip dan menggunakan asumsi tersebut dalam membuat pengetahuan, dimulai dari hal yang umum ke hal yang spesifik.

i. A posteriori knowledge-inductive truth/empirical/bottom-down, kebenaran yang dimulai dengan membuat pengamatan, mengambil asumsi, melakukan eksperimen seperti halnya metode ilmiah, dimulai dari hal yang spesifik ke hal yang umum.

j. Abductive, pengetahuan yang baru dipahami sebabnya pada amsa kini dengan berjalannya waktu karena kurangnya data pengetahuan dan tidak jelasnya informasi pada waktu itu. ${ }^{16}$

Berdasarkan pemikiran di atas, yang menjadi sumber-sumber kebenaran dalam epistemologi adalah: (1) Tuhan dan Alkitab, merupakan pewahyuan dari pencipta dan bersifat mutlak. (2) Panca indra (senses) merupakan sumber pengetahuan yang didapat secara empiris dan pengalaman yang di dapat dengan interaksi indra. (3) Rasio (reason) merupakan pengetahuan yang didapat dari rasio, pemikiran, penalaran, dan logika. (4) Otoritas (expert) merupakan sumber pengetahuan dari seorang yang ahli. Dalam ruang kelas, hal yang dapat dianggap sebagai sumber informasi otoritas adalah buku teks, guru dan referensi. (5) Intuisi (personal insight) merupakan sumber pengetahuan yang di dapat dengan imajinasi yang muncul dari keyakinan. Kemampuan mendapatkan pengetahuan secara langsung yang bukan merupakan hasil penalaran atau persepsi secara sadar. (6) Saling melengkapi dari sumber-sumber pengetahuan.

Menurut Jan Henrik Rapar, pengetahuan dapat dibagi ke dalam tiga jenis yang dijelaskan sebagai berikut17: (a) Pengetahuan biasa (ordinary knowledge). Pengetahuan ini terdiri dari pengetahuan nir-ilmiah dan pra-ilmiah. Pengetahuan nir-ilmiah adalah hasil pencerapan dengan indera terhadap objek tertentu yang dijumpai dalam kehidupan sehari-hari, termasuk pengetahuan intuitif. Pengetahuan pra-ilmiah adalah hasil pencerapan inderawi dan pengetahuan yang merupakan hasil pemikiran rasional yang tersedia untuk diuji lebih lanjut kebenarannya dengan menggunakan metode ilmiah. (b) Pengetahuan ilmiah (Scientific Knowledge). Yang dimaksudkan dengan pengetahuan ilmiah adalah pengetahuan yang diperoleh lewat penggunaan metodemetode ilmiah yang lebih menjamin kebenaran yang dicapai. Pengetahuan yang demikian dikenal juga dengan sebutan science. (c) Pengetahuan filsafati (Philosophical Knowledge). Pengetahuan filsafati diperoleh lewat pemikiran rasional yang didasarkan pada pemahaman, penafsiran, spekulasi, penilaian kritis, dan pemikiran-pemikrian logis, analitis, dan sistematis. Pengetahuan filsafati adalah pengetahuan yang berkaitan dengan hakikat, prinsip, dan asas dari seluruh realitas yang dipersoalkan selaku objek yang diketahui.

Apakah sebenarnya yang menjadi sumber pengetahuan?. Para filsuf memberi jawaban yang berbeda-beda terhadap pernyataan itu. Plato, Descartes, Spinoza, dan Leibniz mengatakan bahwa akal budi atau rasio adalah sumber utama bagi pengetahuan. Bahkan ada yang secara ekstrem menekankan bahwa aka budi adalah satu-satunya sumber bagi pengetahuan. Para filsuf yang mendewakan akal budi itu berpendapat

\footnotetext{
${ }^{16}$ Tung, Filsafat Pendidikan Kristen, 9

${ }^{17}$ Jan Hendrik Rapar, Pengantar Filsafat (Yogyakarta: Penerbit Kanisius, 1996), 38-39
} 
bahwa setiap keyakinan atau pandangan yang bertentangan dengan akal budi tidak mungkin benar. Bagi mereka, pikiran memiliki fungsi yang amat penting dalam proses mengetahui. ${ }^{18}$ Paham yang menekankan bahwa sumber pengetahuan berasal dari rasio atau akal budi disebut paham atau aliran rasionalisme. Tokoh yang sangat terkenal mengembangkan aliran ini adalah Rene Descartes.

Beberapa filsuf lainnya, seperti Bacon, Hobbes, dan Locke menyatakan bahwa bukan akal budi, melainkan pengalaman inderawilah yang menjadi sumber utama bagi pengetahuan. Kendati ada perbedaan pandangan di antara mereka sendiri, mereka semua sependapat bahwa pada dasarnya pengetahuan bergantung pada pancaindera manusia serta pengalaman-pengalaman inderanya, dan bukan rasio. Mereka juga mengklaim bahwa seluruh ide dan konsep manusia sesungguhnya berasal dari pengalaman. John Locke mengatakan bahwa seluruh ide manusia berasal secara langsung dari sensasi dan lewat refleksi terhadap ide-ide sensitif itu sendiri. Tidak ada suatu apa pun juga dalam akal budi manusia yang tidak berasal dari pengalaman inderawi. ${ }^{19}$ Paham yang menekankan bahwa sumber pengetahuan berasal dari pengalaman inderawi adalah paham atau aliran empirisisme. Tokohnya yang sangat terkenal adalah John Locke.

Imanuel Kant, seorang filsuf yang tidak sealiran dengan John Locke, menjembatani kedua aliran sumber pengetahuan yaitu rasio dan pengalaman inderawi mengatakan bahwa kendati seluruh ide dan konsep manusia bersifat apriori (suatu ide atau konsep ada pada dirinya sendiri) sehingga ada kebenaran apriori, ide dan konsep itu hanya dapat di aplikasikan apabila ada pengalaman. Tanpa pengalaman, seluruh ide dan konsep serta kebenaran apriori tidak akan pernah dapat diaplikasikan. Dengan kata lain, Kant hendak mengatakan bahwa akal budi manusia hanya dapat berfungsi sebagaimana mestinya apabila dihubungkan dengan pengalaman. ${ }^{20}$ Berdasarkan pemikiran dari beberapa filsuf di atas, maka dapat disimpulkan bahwa sumber-sumber pengetahuan berasal dari rasio atau akal budi dan pengalaman inderawi manusia.

Selain itu dilihat dari sumber pengetahuan, Uyoh Sadulloh dalam bukunya Filsafat Pendidikan mengatakan bahwa manusia berusaha mencari pengetahuan dan kebenaran, yang dapat diperolehnya dengan melalui beberapa sumber yaitu pengetahuan wahyu (reveled knowledg), pengetahuan intuitif (intuitive knowledge), pengetahuan rasional (rational knowledge), pengetahuan empiris (empirical knowledge), dan pengetahuan otoritas (authoritative knowledge). ${ }^{21}$

Kelima sumber pengetahuan tersebut akan diuraikan secara singkat sebagai berikut: Pertama, Pengetahuan Wahyu (Reveled Knowledge). Dalam perjalanan hidup manusia, sebagaian manusia memperoleh pengetahuan dan kebenaran atas dasar wahyu yang diberikan Tuhan kepada manusia. Tuhan telah memberi pengetahuan dan kebenaran kepada munusia pilihannya, yang dapat dijadikan petunjuk bagi manusia dalam kehidupannya. Wahyu merupakan firman Tuhan. Kebenarannya adalah mutlak dan abadi. Pengetahuan wahyu bersifat eksternal, artinya pengetahuan tersebut berasal dari luar manusia. Kedua, Pengetahuan intuitif (Intuitive Knowledge). Dalam pengertian umum, intuisi merupakan metode untuk memperoleh pengetahuan tidak berdasarkan penalaran rasio, pengalaman, dan pengamatan indera. Pengetahuan intuitif diperoleh manusia dari dalam dirinya sendiri, pada saat ia menghayati sesuatu.

\footnotetext{
${ }^{18}$ Rapar, Pengantar Filsafat,39

${ }^{19}$ Rapar, Pengantar Filsafat,39

${ }^{20}$ Rapar, Pengantar Filsafat, 40

${ }^{21}$ Sadulloh, Pengantar Filsafat Pendidikan, 30-33
} 
Pengetahuan intuitif muncul secara tiba-tiba dalam kesadaran manusia. Mengenai proses kerjanya, manusia itu sendiri kadangh-kadang tidak menyadarinya.

Pengetahuan ini sebagai hasil penghayatan pribadi, sebagai ekspresi dari keunikan dan individualitas seseorang, sehingga validitas pengetahuan ini sangat bersifat pribadi. Pengetahuan intuitif disusun dan diterima dengan kekuatan visi imaginatif dalam pengalaman seseorang. Kebenaran yang muncul atau tampak dalam karya seni merupakan bentuk pengetahuan intuitif. Khasanah dan kebenaran hati nurani manusia yang dituangkan dalam berbagai tulisan juga merupakan hasil kerja intuisi.

Dalam filsafat ada paham yang menganut pemikiran ini yang disebut kaum intuisisme. Intuisisme merupakan paham yang menganggap bahwa dengan intuisi manusia dapat memperoleh kebenaran hakiki. Dimana manusia memiliki kemampuan khusus, yaitu cara khusus untuk mengetahui yang tidak terikat pada indera maupun penalaran intelektual. Pengetahuan yang diperoleh dengan intuisi bukan pengetahuan yang berasal dari luar diri kita yang bersifat dangkal, melainkan berasal dari dalam diri kita sendiri. Menurut kaum intuisisme, dengan intuisisme kita akan mengetahui dan menyadari diri kita sendiri, mengetahui karakter perasaan dan motif orang, kita mengetahui dan memahami hakikat yang sebenarnya tentang waktu, gerak, dan aspekaspek fundamental di jagat alam raya ini. Dengan intuisi kita dapat menangkap kenyataan yang konkrit.

Kelemahan dari pengetahuan intuisi adalah tidak dapat diuji dengan observasi, perhitungan, atau eksperimen, karena pengetahuan dan kebenaran intuitif tidak hipotetik. Pengetahuan intuitif pun sulit dikembangkan karena validitasnya yang sangat pribadi, dan memiliki watak yang tidak komunikatif, hanya khusus untuk diri sendiri, subjektif, tidak terlukiskan, sehingga sangat sulit mengetahui apakah seseorang memiliki atau tidak.

Ketiga, Pengetahuan Rasional (Rational Knowledge). Pengetahuan rasional merupakan pengetahuan yang diperoleh dengan latihan rasio/akal semata, tidak disertai dengan observasi terhadap peristiwa-peristiwa faktual. Prinsip logika formal dan matematika murni merupakan paradigma pengetahuan rasional, dimana kebenaranya dapat ditunjukan dengan pemikiran abstrak. prinsip pengetahuan rasional dapat di terapkan pada pengalaman indera, tetapi tidak kesimpulan dari pengalaman indera.

Rasionalisme adalah aliran dalam filsafat yang mengutamakan rasio untuk memperoleh pengetahuan dan kebenaran. Rasionalisme berpandangan bahwa akal merupan faktor fundamental dalam pengetahuan. Akal manusia mempunyai kemanpuan untuk mengetahui kebenaran alam semesta, yang tidak mungkin dapat diketahui melalui observasi. Menurut rasionalisme, pengalaman tidak mungkin dapat menguji kebenaran hukum "sebab-akibat" karena peristiwa yang tidak terhingga dalam kejadian alam ini tidak mungkin dapat di observasi. Rasionalisme memberikan kritik terhadap empirisme, bahwa: (1) Metode emperis tidak memberi kepastian, tetapi hanya sampai pada probalitas yang tinggi; (2) Metode empiris, baik dalam sains maupun dalam kehidupan sehari-hari, biasanya bersifat sepotong-potong (piece meal).

Menurut pengakuan kaum rasionalis, mereka mencari kepastian dan kesempurnaan yang sistematis. Penilitian mereka dalam matematika, khusus geometri, mencoba tidak mempercayai pengalaman, melainkan hanya berdasarkan pada suatu penalaran. menurut mereka, penalaran memadai untuk menyusun oksiomaaksioma dasar yang universal memungkinkan kita dapat mengambil kesimpulan khusus dari aksioma tersebut. Aksioma merupakan "selfevident" dan dapat di percaya, bebas dari pengalaman. Oleh karena itu, pengalaman tidak akan dapat membuktikan bahwa aksioma itu salah. Aksioma akan memberikan dasar bagi semua pengetahuan dan kepercayaan. Kesimpulanya bersifat mandiri, yaitu suatu kesatuan yang bersistem. 
Keempat, pengetahuan Empiris (Empirical Knowledge). Pengetahuan emperis diperoleh atas bukti penginderaan, dengan penglihatan, pendengaran, dan sentuhan indera-indera lainya, sehinga kita mempunyai konsep duynia di sekitar kita. Paradigma pengetahuan emperis adalah sains, dimana hipotesis-hipotesis sains diuji dengan observasi atau dengan eksperimen. Aliran yang menjadikan emperis (pengalaman) sebagai sumber pengetahuan di sebut empirisme. Emperisme merupakan aliran dalam filsafat yang membicarakan pengetahuan.Emperisme beranggapan bahwa pengetahuan dapatb diperoleh melalui pengalaman, dengan jalan observasi, atau penginderaan. Pengalaman merupakan faktor fundamental dalam penetahuan, sehingga merupakan sumber dari pengetahuan manusia. Apa yan kita ketahui berasal dari segala apa yang kita dapatkan melalui alat indera. Pengalaman merupakan proses interaksi antara manusia dan lingkunganya. Pengalaman tidak hanya sekedar dunia fakta, melainkan termasuk pula dunia penelitian, dimana dalam pengertian ini termasuk dunia sains.

Pengalaman bukanlah sesuatu yang bertantangan dengan akal, melainkan melibatkan akal sebagai bagian integral dari pengalaman. Dalam sains moderen, tidak semata-mata pada persepsi indera secara umum dari pengalaman-pengalaman akan selalu bersifat sementara, dan dimulai dari bentuk hipotesis. Oleh karena itulah, teori atau hukum-hukum yang diperoleh melalui pengalaman setiap saat dapat berubah dan dapat diubah, sesuai dengan hasil temuan baru yang berdasarkan pengalaman pula.

Kelima, pengetahuan Otoritas (Authoritadiive Knowledge). Kita menerima suatu pengetahuan itu benar bukan karena telah menceknya diluar kita, melainkan telah dijamin oleh otoritas (suatu sumber yang beribawa, memiliki wewenang, berhak) di lapangan. Kita menerima pendapat orang lain, karena ia adalah seorang pakar dalam bidangnya. Misalnya kita menerimah petuah agama dari seorang kiai, karena beliau merupakan orang yang sangat ahli dan menguasai sumber ajaran agama islam,tanpa kita mencek dari sumber aslinya (Quran dan Sunnah). Kita sering mengutamakan pandangan kita dengan mengutip dari ensiklopedia atau hasil karya tulis para pakar yang terkenal. Pada saman kerajaan, sabda raja merupakan manusia yang paling berkuasa.

Persoalan yang muncul berikutnya adalah bagaimana mengukur pengetahuan kita benar atau salah. Ukuran apakah yang dapat diterapkan pada proposisi-proposisi untuk menentukan kebenarannya atau kenyataannya. Ukuran kebenaran sesungguhnya tergantung pada apakah sebenarnya yang diberikan kepada kita oleh metode-metode untuk memperoleh pengetahuan. Jika apa yang kita ketahui ialah ide-ide kita, maka pengetahuan hanya dapat terdiri dari ide-ide yang dihubungkan secara tepat, kebenaran merupakan keadaan-saling-berhubungan (coherence) di antara ide-ide tersebut atau keadaan saling berhubungan di antara proposisi-proposisi. Jika sebaliknya, kita dengan suatu cara tertentu mengetahui kenyataan, maka pengetahuan atau ide-ide yang benar terdiri dari - seperti yang dikatakan Spinoza - kejumbuhan antara ide dengan ideantumnya, atau selanjutnya kesesuaian (correspondence) antara ide-ide dengan apa yang diwakili. ${ }^{22}$

Beberapa teori yang dapat dijadikan acuan untuk menentukan apakah ukuran pengetahuan itu benar atau salah, yaitu: Teori korepondensi; Teori koherensi, dan Teori pragmatisme. Pertama, Teori Korespodensi (Correspondence Theory). Paham yang mengatakan bahwa suatu pernyataan itu benar jika makna yang dikandungnya sunguhsungguh merupakan halnya, dinamakan "paham korespondensi". Keadaan atau keadaan benar berupa kesesuaian (correspondence) antara makna yang dimaksudkan oleh suatu pernyataan dengan apa yang sungguh-sungguh merupakan halnya, atau apa yang

${ }^{22}$ Sadullo, Pengantar Filsafat Pendidikan, 175 
merupakan fakta-faktanya. ${ }^{23}$ Apakah yang dimaksudkan dengan istilah kesesuaian?. Menurut K. Rogers seorang penganut realisme kritis dari Amerika, mengatakan bahwa kesesuaian itu berlaku di antara esensi-esensinya. Setiap esensi mempunyai dua segi, yang satu terdapat di dalam objeknya dan yang lain sebagai makna. Segi esensi yang berupa makna bersifat kejiwaan. Dalam suatu pencerapan, kita secara diam-diam mengenal esensi yang termasuk objeknya, maupun apa yang dimaksudkan oleh esensi tersebut. Dengan kata lain, apa yang dikatakan oleh Rogers ialah, bahwa keadaankeadaan terletak dalam kesesuaian antara esensi atau makna yang kita berikan dengan esensi atau makna yang terdapat di dalam objeknya. Maka yang berkesesuaian itu bukanlah makna dengan objeknya, melainkan esensi sebagai makna dengan esensi yang terdapat di dalam objek. ${ }^{24}$

Menurut teori korespodensi, kebenaran merupakan persesuaian antara fakta dan situasi nyata. Kebenaran merupakan persesuaian antara pernyataan dalam pemikiran dengan situasi lingkungannya. Teori ini paling luas diakui oleh kaum realis. Sebagai contoh, saya berpendapat bahwa pulau Jawa merupakan pulau terdapat penduduk di Indonesia . pendapat saya itu benar bukan karena bersesuai dengan pendapat orang lain sebelumnya, atau karena di terima oleh banyak orang, melainkan karena persesuaian dengan kenyataan yang sebenarnya. Ini merupakan ciri dari ilmuan yang selalu mencek atau mengontrol pikiran-pikirannya dengan data-data atau penemuan-penemuan. ${ }^{25}$

Kedua, Teori Koherensi (Coherence Theory). Penganut kohenrensi tentang kebenaran biasanya dianut oleh para pendukung idealisme, seperti filsuf Britania F.H. Bradley (1846-1924). Secara singkat paham tersebut mengatakan bahwa suatu proposisi cenderung benar jika proposisi tersebut dalam keadaan saling berhubungan dengan proposisi lain yang benar, atau jika makna yang dikandungnya dalam keadaan saling berhubungan dengan pengalaman kita. Contoh, bagaimana cara kita mengatakan bila seseorang bohong dalam banyak hal? Jawabnya dengan jalan menunjukkan bahwa apa yang dikatakan tidak cocok dengan hal-hal lain yang telah dikatakannya atau dikerjakannya. ${ }^{26}$

Teori koherensi menganut hukum-hukum keadaan saling berhubungan. Bradley mengatakan bahwa yang dimaksudkan para penganut idealis tentang hukum-hukum keadaan saling berhubungan, dapat diketahui dari dua ciri pokok, yaitu: Pertama, adanya keharusan bahwa semua fakta terangkum. Ide-ide tidak mungkin saling berhubungan jika ide-ide itu hanya merupakan bagian-bagian dari kebenaran seluruhnya. Kedua, ide-ide tersebut harus teratur secara selaras dan tidak mengandung kontradiksi. Kenyataan (dan karenanya, kebenaran) oleh para penganut idealisme digambarkan sebagai sistem kebenaran yang teratur, yang logis, yang didalamnya tidak terdapat kontradiksi. ${ }^{27}$

Menurut teori koherensi, kebenaran bukan bersesuai antara pikiran dengan kenyataan , melainkan kesesuaian secara harmonis antar pendapat/pikiran kita dengan pengetahuan kita yang telah dimiliki. Teori ini pada umumnya diakui oleh golongan idealis. Pengertian persesuaian dalam teori ini terdapat konsistensi (ketetapan, sehingga teori ini berarti terdapat konsistensi (ketetapan, sehingga teori ini disebut juga teori konsistensi) yang merupakan ciri logis hubungan antara pikiran-pikiran (ide-ide) yang telah kita miliki satu dengan yang lain. Kalau kita menerima pengetahuan baru, karena pengetahuan tersebut sesuai dengan pengetahuan yang kita miliki,atau apa bilah kita

\footnotetext{
${ }^{23}$ Lois O. Kattsoff, Pengantar Filsafat (Yogyakarta: Tiara Wacana Yogya, 2004), 179

${ }^{24}$ Kattsoff, Pengantar Filsafat, 180

${ }^{25}$ Sadullo, Pengantar Filsafat Pendidikan, 175

${ }^{26}$ Kattsoff, Pengantar Filsafat, 180

${ }^{27}$ Kattsoff, Pengantar Filsafat, 177
} 
melepaskan pendapat lama, karena pendapat baru tersebut lebih bertautan secara harmonis dengan keseluruhan pangalaman pengetahuan kita.

Bentuk yang paling sederhana dari teori koherensi adalah menurut adanya konsestensi formal dalam sistem. Misalnya dari rumus-rumus matematika orang dapat membangun suatu sistem dalam geometri. Sistem ini dapat diakui sebagai suatu sistem dalam geometri. Sistem ini dapat di akui sebagai suatu sistem adalah adanya konsistensi dengan hukum-hukum berfikir pormal tertentu.

Golongan idealis cenderung untuk memperlus sistem konsistensi ini dengan memasukan semua pengalaman yang bersifat konsisten dalam dirinya. Plato, Hegel, Bradley, dan Royce, memperluas prinsip-prinsip konsistensi ini dengan memasukan sistem jagat raya. Sehingga setiap pikiran yang benar dan setipa bagian-bagian sistem kebenaran berkaitan dengan kenyataan secara keseluruhan dalam jagat raya dan memperoleh makna/ arti dalam keseluruhan tersebut. Berdasarkan prinsip-prinsip ini, kebenaran merupakan sistem dalil-dalil yang konsisten secara timbal balik,dan setiap dalil memperoleh kebenaranya dalam keseluruhan sistem.

Beberapa kritik diberikan pada teori ini, diantaranya; pertama, kita tidak dapat membangun sistem keterpaduan (coherent system) yang salah.teori ini tidak dapat membedakan antara kebenaran yang konsisten dangan kekeliruan yang konsisten. Para pengkritik menunjukkan bahwa banyak sistem pada masa lampau secara logis konsisten, tetapi secara fakta ternyata kemudian salah (contohnya pertantangan antara sistem heliosentris telah menimbulkan korban ilmuwan basar, yaitu Galileo). Kedua, teori ini bersipat rasionalistis dan intelektualistis, dan hanya mementingkan hubungan logis antara dalil-dalil. Sebagai akibatnya, teori ini gagal memperlengkapi tes/pengujian yang memadai terhadap pikiran dari pengalaman sehari-hari. Teori ini hanya cocok untuk matematika murni. Teori ini tidak cocok untuk menguji kebenaran berdasarkan fakta.

Ketiga, Teory Pragmatisme (Pragmatism Theory). Menurut teori pragmatisme, kebenaran tidak bersesuai dengan kenyataan, sebab kita hanya bisa mengetahui dari pengalaman kita saja. Di lain pihak, menurut pragmatisme, teori koherensi adalah normal dan rasional. Pragmatisme berpendirian bahwa mereka tidak mengetahui apapun (agnostik) tentang wujud, esensi, intelektualitas, rasionalitas. Oleh klarena itu, pragmatisme merupakan penganut emperisme yang fanatik untuk memberikan interperensi terhadap pengalaman. Menurut pragmatisme, tidak ada kebenaran yang mutlak dan abadi. Kebenaran itu dibuat dalam proses penyusaian manusia.

Schiller, pengikut pragmatisme di Inggris, mengemukakan bahwa kebenaran merupakan suatu bentuk nilai, artinya apabila kita menyatakan benar terhadap sesuatu, berarti kita memberikan penilain terhadapnya. Istilah benar adalah suatu pernyataan yang berguna, sedangkan istilah salah merupakan pernyataan yang tidak berguna. Seseorang menyatakan pendapatnya bahwa benar, karena telah memenuhi kepentinganya. Dapat terjadi seseorang menyatakan benar, tetapi suatu saat ia menyatakan pendapatnya itu salah, karena pendapatnya itu sudah tidak berguna, tetapi hanya dapat memenuhi kepentinganya. Tetapi, dalam hal ini tidak berarti bahwa benar dan salah merupakan hal yang bersifat individual. Kebenaran merupakan hasil hubungan sosial. Kebenaran individual dikontrol atau dikoreksi di bawah pengaruh sosial, sampai akhirnya kebenaran itu diterima secarah umum.

Menurut pragmatisme, kebenaran suatu pernyataan diukur dengan kriteria apakah pernyataan tersebut bersifat fungsional dalam kehidupan praktis atau tidak. Artinya, pernyataan itu dikatakan benar kalu memiliki kegunaan praktis dalam kehidupan manusia. Suatu teori, pendapat, atau hipotesis dikatakan benar apabila 
menghasilkan jalan keluar dalam praktik, atau membuahkan hasil-hasil yang memuaskan.

Menurut para pendukung pragmatisme, kebenaran suatu pernyataan diukur dengan kriteria apakah pernyataan tersebut bersifat fungsional dalam kehidupan praktis atau tidak. Artinya pernyataan itu dikatakan benar jika mempunyai kegunaan praktis dalam kehidupan manusia. Suatu teori, pendapat, atau hipotesis dikatakan benar apabila menghasilkan jalan ke luar dalam praktik, atau membuahkan hasil-hasil yang memuaskan. Para pendukung pragmatisme cenderung memberikan tekanan pada tiga pendekatan yaitu: (1) Bahwa sesuatu dikatakan benar apabilah memuaskan atau memenuhi keinginan-keinginan atau tujuan-tujuan manusia. Kepercayaan akan berdasarkan bukan hanya memberikan kepuasan bagi seluruh sifat dasar manusia, melainkan juga memberi kepuasan selama jangka waktu tertentu. (2) Bahwa sesuatu itu benar apabila dapat dikaji kebenaranya secara eksperimen. Penguji kebenaran ini selaras dengan semangat dan praktis sains modern, baik dalam laboratorium maupun dalam kehidupan sehari-hari. Begitu suatu kebenaran atau ketidak benaran muncul,maka kita hendaknya mencoba dan mengatakan buktinya. (3) Bahwa sesuatu itu benar apabila membantu dalam perjuangan hidup bagi eksistensi manusia. Instrumentalisme Dewey menekan-kan fungsi bagi kehidupan dari ajaran serta ideidenya .

Para penganut ajaran-ajaran pragmatisme berbeda-beda coraknya, sesuai dengan konsekuensi-konsekuensi yang mereka tekankan. Namun, semua penganut pragmatisme meletakkan ukuran kebenaran dalam salah satu macam konsekuensi. Sebagai contoh, William James, mengatakan bahwa proposisi "Tuhan ada" adalah benar bagi seseorang yang hidupnya mengalami perubahan karena percaya adanya Tuhan. Ini berarti bahwa proposisi-proposisi yang membantu kita mengadakan penyesuaianpenyesuaian yang memuaskan terhadap pengalaman-pengalaman kita, adalah benar. Dalam batas-batas tersebut, kebenaran merupakan gagasan yang berguna atau dapat dilaksanakan di dalam suatu situasi. Dan orang mempunyai kehendak serta hak untuk percaya akan hal-hal yang membantu menetapkan hubungan yang memuaskan dengan sisa pengalaman mereka. Kiranya jelas, bahwa kesulitan besar tentang definisi mengenai kebenaran sebagai sesuatu uang berguna dalam menetapkan penyesuaian-penyesuaian yang memuaskan, tergantung pada apa yang dimaksudkan dengan "dapat dilaksanakan" atau "berguna", dan tergantung pada apakah yang merupakan hubungan-hubungan yang memuaskan dengan sisa pengalaman kita. ${ }^{28}$

Karena itu untuk mencari kebenaran, kaum pragmatis berpaling pada metode sains (ilmiah), sebab, metode ini dianggapnya berfungsi dan berguna dalam menafsirkan gejala-gejala alam. Kriteria pragmatisme banyak digunakan oleh ilmuan untuk menentukan kebenaran ilmiah dalam jangka waktu tertentu, karena seperti yang telah dikemukakan di atas, bagi pragmatisme tidak ada kebenaran mutlak dan abadi. Beberapa teori dari pragmatisme: Pertama, teori Kesahihan Semantik (Semantik theory of Truth). Perihal teori Kesahihan Semantik (Semantik theory of Truth) dan Teori Kesahihan Logikal yang berlebih-lebihan (Logical Superfluity Theory of Truth) dikutip dari tulisan Jan Hendrik Rapar. ${ }^{29}$ Yang dimaksudkan teori Kesahihan Semantik (Semantik theory of Truth) adalah teori yang menekankan arti dan makna suatu proposisi. Bagi teori kesahihan semantik, proposisi harus menunjukkan arti dan makna sesungguhnya yang mengacu kepada referen atau realitas dan bisa juga arti definitif dengan menunjuk ciri khas yang ada. Kedua, teori Kesahihan Logikal yang berlebihlebihan (Logical Superfluity Theory of Truth). Adalah sebuah teori yang hendak menunjukkan bahwa proposisi logis yang memiliki term berbeda tetapi berisi informasi

\footnotetext{
${ }^{28}$ Kattsoff, Pengantar Filsafat, 182-183

${ }^{29}$ Rapar, Pengantar Filsafat, 43
} 
sama tak perlu dibuktikan lagi, atau ia telah menjadi suatu benda logik yang berlebihlebihan. Contoh: siklus adalah lingkaran atau lingkaran adalah bulatan dan sebagainya. Dengan demikian, proposisi lingkaran atau bulat tidak perlu dibuktikan lagi kebenarannya. ${ }^{30}$

Di sini sangat dibutuhkan sekolah Kristen harus bersumber pada firman Tuhan dalam mendapatkan pengetahuan. Sekolah Kristen harus memiliki kurikulum dengan sudut pandang Alkitab di dalamnya. Amsal 3:5-6 berkata, "Percayalah kepada TUHAN dengan segenap hatimu, dan janganlah bersandar kepada pengertianmu sendiri Akuilah Dia dalam segala lakumu, maka ia akan meluruskan jalanmu." Landasan epistemologi pendidikan Kristen adalah firman Allah seperti yang dinyatakan dalam Alkitab, "FirmanMu itu pelita bagi kakiku dan terang bagi jalanku (Mzm. 119:150). Landasan ini akan menjadi tugas panggilan pendidik dalam pelayanan di sekolah. Kebenaran firman Tuhan harus dipahami sebagai kesatuan (unity) dalam tritunggal Allah: (1) Firman yang berkenaan dengan penciptaan, (2) Firman yang hidup berinkarnasi dalam Yesus Kristus (Yoh. 1:14). (3) Firman yang dituliskan untuk menuntun manusia, Alkitab (2 Tim. $3: 16) .^{31}$

Menurut Pazmino pertanyaan-pertanyaan epsitemologi berdampak langsung terhadap konsep pendidikan seseorang yang terkait tentang dasarnya, pandangannya mengenai manusia dan tujuan umum dan khususnya dalam pendidikan. Cremin menjelaskan dan dalam pendidikan sama dalam kehidupan, bahwa "ada kesenjangan yang tak terhindarkan antara aspirasi dan prestasi, dan antara idealisme dan realitas. Juga sering muncul kesenjangan antara tujuan yang telah ditetapkan dan preferensi yang diungkapkan. ${ }^{32}$ Namun menurut Knigt kesenjangan ini bisa digunakan untuk mengarahkan usaha-usaha pembaruan menuju pencapaian suatu idealisme. Sekalipun demikian, tantangan yang dihadapi para pendidik Kristen adalah memilih dan mengembangkan dengan ketajaman membedakan manakah praktik-praktik pendidikan yang konsisten dengan kepercayaan mereka, namun tetap mampu mengakomodasi konteks secara politik, sosial, ekonomi dan komunal. ${ }^{33}$

Menurut Crome dalam kaitannya dengan pertanyaan-pertanyaan epistemologis yang substantif sifatnya, para ilmuwan di bidang pendidikan agama telah membuka kembali pembahasan tentang natur pengetahuan dan validitas dari berbagai metode yang dipakai untuk memperoleh pengetahuan. ${ }^{34}$ Tentunya hal ini memaksa para pendidik Kristen untuk mempertimbangkan kembali Kitab Suci sebagai sumber dari semua upaya yang mereka lakukan. Pandangan Alkitab terhadap pengetahuan bersifat holistik dalam arti melibatkan pengetahuan dalam arti kognitif sekaligus perasaan dan tindakan. Pengetahuan mencakup dimensi fisik yag menghasilkan komitmen pribadi dan tuuan untuk mengenal seseorang atau mengetahui. Dalam hal mengenal Allah, pengenalan ini akan diwujudkan dalam bentuk respons yang mengasihi, menaati, dan mempercayai Dia. Ini merupakan cara yang bersifat rasional/berdasarkan pengalaman/reflektif yan dibangun diatas penyataan Allah sebagimana dijabarkan di dalam Kitab Suci.

Selanjutnya Palker Palmer, dalam usahanya menemukan epistemologi yang alkitabiah, mengatakan bahwa pengetahuan sebagaimana yang dimengert dalam konteks masyarakat harus dikaitkan dengan minat dan hasrat manusia yang sering kali diabaikan. Dalam analisisnya, Palmer mengatakan bahwa pengetahuan dapat dikaitkan

\footnotetext{
${ }^{30}$ Rapar, Pengantar Filsafat, 43

${ }^{31}$ Tung, Filsafat Pendidikan Kristen, 10-11

${ }^{32}$ Lawrence A. Cremin, Public Education (New York: Basic Books, 1976), 36

${ }^{33}$ Pazmino, Fondasi Pendidikan Kristen, 127

${ }^{34}$ Pazmino, Fondasi Pendidikan Kristen, 128
} 
pada tiga macam minat atau hasrat manusia, yakni: kendali, keingintahuan dan belaskasihan. Pengetahuan yang diperoleh melalui studi empiris dan analitis biasanya bertujuan untuk mengendalikan sejumlah informasi tertentu. Pengetahuan yang diperoleh melalui studi spekulatif, historis, dan hermeneutik biasanya bertujuan untuk memperoleh pengetahuan sebagai tujuan memuaskan keingintahuannya. Pengetahuan yang membebaskan dijelaskan di dalam 1 Korintus 8:1-3 "Tentang daging persembahan berhala kita tahu: 'Kita semua mempunyai pengetahuan.' Pengetahuan yang demikian membuat orang sombong, tetapi kasih membangun. Jika ada seorang menyangka, bahwa ia mempunyai sesuatu 'pengetahuan', maka ia belum juga mencapai pengetahuan, sebagaimana yang harus dicapainya. Tetapi orang yang mengasihi Allah, ia dikenal oleh Allah. Pengetahuan jenis ini diasosiakan dengan minat untuk berbelas kasihan atau untuk mengasihi. ${ }^{35}$

Tentu saja demikian dalam Perjanjian Baru tetap mempertahankan bahwa pengetahuan atau kebenaran itu haruslah dikaitkan dengan kasih (Ef. 4:15, 2 Yoh. 1) dan bahwa seluruh kebenaran adalah kebenaran Allah, karena Dia adalah sumber segala pengetahuan, hikmat dan pengertian (Kol.2:2-3). Misalnya yang dihadapi pendidikan Kristen adalah bagaimana mempertahankan kebenaran dalam suatu tekanan untuk membedakan manakah kebenaran yang diperoleh lewat penelitian dari berbagai disiplin ilmu dan manakah kebenaran yang dinyatakan di Alkitab dan pada saat bersamaan para pendidik Kristen tetap menunjukkan kasih kepada Allah, sesama dan ciptaan lainnya. Inilah doa Tuhan Yesus supaya murid-murid-Nya disucikan oleh kebenaran Allah, dengan kesadaran bahwa Firman Allah adalah kebenaran (Yoh. 17:17). Kristus menyatakan bahwa Dia adalah inkarnasi dari kebenaran itu (Yoh, 14:6). ${ }^{36}$

Kita bersyukur, dari penelitian para ahli seperti dari pemaparan George Knight kita menemukan penggalian dan observasi epistemologi alkitabiah yang dapat menuntun para pendidik Kristen menghayati panggilannya, demikian:

a. Perspektif Alkitab menyatakan bahwa seluruh kebenaran adalah kebenaran Allah dan itu berarti mengiliminasi adanya perbedaan antara kebenaran sekular dan rohani.

b. Kebenaran dari pernyataan kristiani adalah benar adanya sesuai dengan apa yang ada di alam semesta, sehingga orang Kristen bisa mengejar kebenaran tanpa rasa takut menghadapi terjadinya kontradiksi yang bersifat ultimat.

c. Kekuatan jahat berusaha merendahkan Alkitab, membelokkan pemikiran manusia, dan mengarahkan manusia untuk bergantung pada ketidakmampuan diri sendiri yang sudah jatuh dalam dosa dalam upayanya mengejar kebenaran.

d. Alkitab tidak hanya berisi kebenaran abstrak, tetapi juga kebenaran yang berkaitan dengan kehidupan. Karena itu, mempunyai pengetahuan dalam pengertian Alkitab adalah menerapkan pengetahuan yang sudah didapat dalam kehidupan sehari-hari.

e. Berbagai sumber pengetahuan tersedia bagi orang Kristen (penyataan khusus dari Alkitab, penyataan umum dari alam semesta dan pikiran) yang bersifat saling melengkapi dan seharusnya dipergunakan menurut pola yang alkitabiah.

f. Dengan adanya keutuhan kebenaran, penerimaan terhadap epistemologi kristiani tidak bisa dipisahkan dari metafisik kristiani. ${ }^{37}$

\footnotetext{
${ }^{35}$ Parker J.Paker, To Know as We Are Known: A Spritually of Education (San Fransisco:Harper \&Row, 1983), 6-10

${ }^{36}$ Pazmino, Fondasi Pendidikan Kristen, 130

${ }^{37}$ George R. Knight, Philosophy and Education An Introduction In Christian Perspektive ( Berrien Springs, MI: Andrews University Press, 1980), 161-162
} 
Hasil observasi Knight ini menolong pendidik Kristen menghadapi tantangan masa kini dari pihak saintifisisme kontemporer yang mengatakan bahwa penelitian ilmiah adalah satu-satunya cara mengetahui yang bisa diandalakan. Saintifisisme, yang dikontraskan dari ilmu pengetahuan, menyangkal bahwa kebenaran bisa diperoleh lewat penyataan iman Kristen dan berasumsi bahwa pemikiran yang didasarkan pada penelitian ilmiah merupakan cara satu-satunya untuk memperoleh pengetahuan dan kebenaran. Bahkan Huston Smith dalam tulisnnya "Exclude Knowledge: A Critique of the Moderm Western Mind Set, Teacher Collage Record" yang dikutip Pazmino menunjukkan bahaya dari epistemologi yang terbatas seperti itu. Ilmu pengetahuan menghargai kontrol, prediksi, objektivitas, angka, dan tanda, sementara iman menghargai penyerahan, kejutan, subjektivitas, dan objektivitas, kata-kata dan simbol. Ilmu pengetahuan berusan dengan nilai kegunaan instrinsik dari keajaiban, kekaguman, penghormatan, kreatifitas, imajinasi, dan janji. Dimana kalau "menjadi" adalah fokus dominan ilmu pengetahuan, sementara "keberadaan/menjadi" adalah fokus iman. ${ }^{38}$

Perspektif kekristenan dalam hal iman memberikan sebuah alternatif dalam memperoleh pengetahuan yang meluas, tetapi tidak bertentangan dengan kebenran ilmu pentahuan, karena seluruh kebenaran adalah kebenaran Allah. Orang Kristen bebas mengeksplorasi ide-ide penting dalam ilmu pengetahuan, yang ditemukan atau dihasilkan melalui pemikiran dan observasi empiris terhadap dunia sebagai penyataan umum dari Allah. Namun orang Kristen harus sadar akan potensi dari kekuatan jahat yang berusaha mengangungkan ilmu pengetahuan dengan cara yang tidak tepat. Cara pandang kekristenan terhadap dunia dan alam ini menunjukkan bahwa seluruh ciptaan rill dan terbuka terhadap percobaan; ilmu pengetahuan yang bersifat empiris bisa diafirmasi kebenarannya. Pandangan kristiani juga mempertahankan bahwa alam itu teratur dan bisa diselidiki dengan intelegensi, karena itu, ilmu pengetahuan yang teoritis adalah benar. Akhirnya, pandangan kristiani mempertahankan bahwa sejarah dan budaya punya makna dan tujuan. Maka dari itu, ilmu pengetahuan terapan dan teknologi bisa dipelajari sepenuhnya. ${ }^{39}$

Kekristenan sangat terbuka terhadap ilmu pengetahuan. Bahkan Kitab Suci dan penebusan Kristus justru harus menerangi dan dirasakan serta dialami dalam setiap aspek kehidupan termasuk dalam ilmu pengetahuan. Joseph Spradley menjelaskan cara pandang kristiani terhadap ilmu pengetahuan bahwa kekristenan memandang alam di bawah terang Kitab Suci namun tetap peduli terhadap budaya. Hal ini melibatkan suatu pandangan yang kreatif terhadap alam sebagai suatu yang rill dan baik. Kekristenan juga memiliki suatu pandangan yang kritis terhadap gagasan dan metode ilmiah dengan cara menjadikan Alkitab sebagai panduannua, dan iman untuk melihat keteraturan dan potensi untuk dipahami yang diungkapkan dalam ciptaan. Dalam pandangannya seperti ini terkandung upaya untuk membangun suatu pandangan yang konstruktif terhadap budaya agar menemukan tujuan dan maknanya, sehingga bisa menciptakan dunia yang lebih baik bagi kemanusiaan dan kemuliaan Allah. ${ }^{40}$

Dari sini kita memahami bahwa dalam cara pandangn epistemologi kristiani ada bahaya dan anugerah di dalam ilmu pengetahuan. Tugas pendidik Kristen adalah memahami dan mengantisipasi potensi bahaya dari ilmu pengetahuan tetapi

\footnotetext{
${ }^{38}$ Pazmino, Fondasi Pendidikan Kristen, 131

${ }^{39}$ Joseph Spradley, "A Christian View of the Physical World" dalam The Making of a Christian Mind: A Chistian World View and the Academic Enterprice, ed.Arthur F. Holmes (Downers Grove II: InterVarsity, 1985), 59-69.

${ }^{40}$ Joseph Spradley, "A Christian View of the Physical World" dalam The Making of a Christian Mind: A Chistian World View and the Academic Enterprice, 79.
} 
IMPLEMENTASI SISTEMATIKA FILSAFAT ... (Dyulius Thomas Bilo)

memperjuangkan kesejahteraan manusia melalui ilmu pengetahuan dalam terang anugerah, penebusan Kristus dan Alkitab. Anugerah Allah terhadap ilmu pengetahuan dapat melawan bahaya yang muncul dari saintifisme. Pazmino dengan dibantu mahasiswanya membuat tabel ilmu pengetahuan dan anugerah Allah:

\section{Gambar 1}

\section{TABEL ILMU PENGATAHUAN DAN ANUGERAH TUHAN}

\begin{tabular}{|c|c|c|}
\hline Potensi Ilmu Pengetahuan & Bahaya dalam Saintifisme & Anugerah Tuhan \\
\hline Penjelasan (mengetahui) & Penyembahan yang salah tempat & Iman \\
\hline Prediksi (memilih) & Harapan yang tidak terjamin & Harapan \\
\hline Kontrol (mengubah) & Penyalahgunaan kekuasaan & Kasih \\
\hline
\end{tabular}

Pazmino menjelaskan secara singkat bahwa potensi pertama dari ilmu pengetahuan adalam memberikan penjelasan tentang realitas dan memberikan kontribusi pada pengetahuan manusia. Namun, ada bahaya yang potensial yaitu penyembahan yang salah tempat, yang memuliakan proses ilmiah atau penjelasan manusia yang diperoleh dari proses tersebut. Iman Kristen bisa membantu memfoskuskan penyembahan itu terhadap Allah Pencipta yang menyatakan diri-Nya kepada manusia lewat alam ini. Potensi kedua dari ilmu pengetahuan adalah memprediksi fenomena alam dan berkontribusi pada proses pengambilan keputusan manusia. Namun, bahaya yang ada di dalamnya adalah harapan yang tidak terjamin terkait kejadian-kejadian di masa depan dan kemampuan manusia untuk menentukan kejadian-kejadian tersebut. Anugerah Allah dari harapan yang hidup mengingatkan orang Kristen akan kemahakuasaan Allah dan pemeliharaan-Nya dengan tidak mengabaikan tanggung jawab manusia untuk memprediksi dan memilih masa depan. Potensi ketiga dari ilmu pengetahuan, yang diidentifikasi Palmer adalah kontrol dan perubahan kondisi alam atau kondisi manusia. Bahaya yang menyertai potensi ini adalah penyalagunaan kekuasaan, yang terus menerus disaksikan dalam sejarah. Mengimbangi bahaya ini adala anugerah Allah dalam kasih kristiani yang murni, yang menempatkan kemuliaan Allah, kesejahteraan orang lain dan ciptaan di atas kepentingan kekuasaan. ${ }^{41}$

Dalam penutupnya menarik Pazmino menjelaskan bahwa dalam diskusi tentang saintifisme ini mengilustrasikan pentingnya epistemologi alkitabiah dan penggunaan observasi Knight dalam rangka mempertimbangkan pertanyaan-pertanyaan epistemologi. Kebenaran-kebenaran dari ilmu pengetahuan bisa diintegrasikan dengan cara pandang kristiani yang mengafirmasi bahwa seluruh kebenaran adalah kebenaran Allah. Orang Kristen tentu saja dapat mengejar pengetahuan yang ilmiah asalkan tidak bertentangan dengan evaluasi teologisnya. Kebenaran yang alkitabiah bisa membuat kita mengenal bahaya-bahaya yang terkandung dalam penyalahgunaan ilmu pengetahuan. Sebuah epistemologi Kristen itu bergantung pada metafisik Kristen dan secara khusus kosmologi Kristen, yang melihat dunia ini sebagai ciptaan Allah dan sebab itu harus tunduk kepada Allah dalam segala variasi dan keutuhannya.

Alkitab dengan sangat jelas menunjukkan berbagai-bagai aspek penting tentang pengetahuan yang dapat dipelajari oleh orang-orang percaya untuk merumuskan suatu kurikulum yang alkitabiah. Itulah sebabnya epistemologi alkitabiah yang benar-benar sesuai firman Tuhan menjadi sesuatu keharusan yang perlu dikaji dan dikembangkan dalam kurikulum pendidikan Kristen. Di sini para pendidik diharapkan untuk

\footnotetext{
${ }^{41}$ Pazmino, Fondasi Pendidikan Kristen,132-133.
} 
membekali diri dengan pengetahuan-pengetahuan yang bersumber dari Alkitab sehingga mampu membentuk epistemologi yang benar-benar sesuai firman Tuhan.

\section{Tinjauan Aksiologi bagi Pengembangan Kurikulum Pendidikan Kristen}

Aksiologi adalah cabang dari filsafat yang mencari jawab tentang nilai, "what is of value?". Aspek yang sangat terkait dengan aksiologi adalah etika dan estetika. Aksiologi adalah cabang filsafat yang membahas nilai baik dan nilai buruk, indah dan tidak indah. Hal ini erat kaitannya dengan pendidikan karena dunia nilai akan selalu dipertimbangkan atau menjadi dasar pertimbangan dalam menentukan tujuan pendidikan. langsung atau tidak, nilai akan menentukan perbuatan pendidikan. Nilai merupakan hubungan sosial. ${ }^{42}$ Maka aksiologi sangat berkaitan erat dengan hubungan manusia dengan alam dan secara sosial. Etika merupakan studi tentang nilai-nilai moral dan perilaku. Maka aksiologi menjawab pertanyaan "apakah itu kebaikan, apakah yang seharusnya dilakukan orang pada saat situasi seperti ini?". Estetika adalah studi dari nilai-nilai umum, prinsip yang mengatur penciptaan dan penghargaan terhadap keindahann dan seni. Estetika menjawab pertanyaan "apa itu keindahan, apa yang indah dari seni tersebut?"

Pertanyaan-pertanyaan tentang nilai melibatkan baik etikan maupun estetika. Etika adalah studi tentang prinsip moral dan praktiknya. Etika Kristen berusan dengan realitas dosa dan panggilan kristiani untuk melayani dan berkorban bagi dunia. Estetika adalah studi tentang keindahan dan dimensi kreatif dalam hidup. Bagi orang Kristen, estetika didasarkan pada fakta bahwa Allah menciptakan dunia itu indah; dan ini mengimplikasikan suatu tanggung jawab pribadi baik untuk menghargai maupun untuk mencintai keindahan. Dalam dunia pendidikan faktor aksiologis sangat ditekankan dalam suatu proses pendidikan. Paulo Freire mengatakan tujuan, integritas, dan kejujuran yang berkaitan dengan nilai-nilai tersebut yang akan memandu seluruh proses pendidikan. Semuanya itu merupakan hal yang bersifat fundamental bagi setiap praktik pendidikan Kristen

Dalam dunia pendidikan aksiologi menyokong guru menentukan nilai-nilai apa yang harus ekspresi kemanusiaan yang tertinggi?, dan nilai-nilai apa yang benar-benar dipegang orang yang benar-benar terdidik?. ${ }^{43}$ John W. Gadner dalam tulisannya "Engagement of Values in Public Life" bahwa ada empat implikasi bagi para pendidikan mengenai aksiologi pendidikan. Pertama, para pendidik Kristen harus sadar akan nilainilai yang mendasari usaha mereka dalam pengajaran, pelayanan dan kehidupan. Kedua, para pendidik Kristen harus menerjemahkan nilai-nilai mereka ke dalam tujuan umum dan khusus secara aktual sebagai pemandu dari praktik pendidikan mereka. Nilai-nilai itu harus disintesiskan dan diinternalisasikan ke dalam seluruh upaya pendidikan, sehingga orang-orang dapat didorong untuk bertindak secara konsisten selaras dengan nilai-nilai yang telah dinyatakan. Ketiga, bahwa nilai-nilai itu harus dikejar dalam kontek komunal dan institusional, karena kita hidup dalam dunia yang komunal dan intensional. Sering kali nilai-nilai ini dianggap sebagai sesuatu yang bersifat pribadi sekali dan seringkali terlalu menekankan subjektivitas yang berpusat pada diri sendiri dan bisa menjangkiti orang Kristen yang berakibat pada psikologinasi penginjilan (kedamain saya, sukacita saya, identitas diri saya, harga diri sayam kesehatan saya dan....saya). Keempat, para pendidik Kristen harus sadar akan kebutuhan konstan untuk memperbaharui nilai-nilai mereka. Dengan mengingat natur manusia, komunitas, institusi, dan struktur sosial, orang Kristen harus secara konstan mengafirmasi nilai-

\footnotetext{
${ }^{42}$ Simanjuntak, Filsafat Pendidikan dan Pendidikan Kristen, 102

${ }^{43}$ Simanjuntak, Filsafat Pendidikan dan Pendidikan Kristen, 102
} 
nilai mendasar yang alkitabiah dalam pertempuran rohani demi pemikiran dan hidup orang. ${ }^{44}$ Paul Tillich mengatakan bahwa orang Kristen dipanggil untuk terus menerus hidup berdasarkan prinsip Protestan, yang mempertahankan bahwa reformasi dan pembaruan selalu dibutuhkan dalam institusi mengingat adanya kebutuhan, kondisi, dan isu-isu kehidupan kontempores yang terus berubah. Tugas orang Kristen adalah melawab semua usaha, bentuk dan struktur yang tidak sesuai dengan Injil untuk kemudian menyarankan alternatif-alternatifnya sesuai dengan nilai kekristenan. Dan karya Roh Kudus sangat diperlukan untuk mewujudkan reformasi dan pembaruan secara efektif. ${ }^{45}$

Etika dan estetika pendidikan Kristen bertujuan memuliakan Tuhan dan mengasihi sesama. Etika bersumber dari pewahyuan khususm estetika bersumber dari doktrin keindahan realitas ciptaan Allah. Dalam perspektif Kristen, etika adalah bentuk normatif dari suatu panduan yang tidak berubah, tidak subjektif dan tidak situasional. Etika Kristen tidak berbasis pada nilai yang berdasarkan prinsip-prinsip yang ditentukan komunitas atau rentang waktu tertentu, tetapi berdasarkan kebenaran firman Tuhan (Fil. 4:8).

Aspkek aksiologi pendidikan Kristen bersumber pada panggilan pelayanan pendidikan yang: (1) Mencintai Tuhan, (2) Mencintai sesama manusia, (3) Mencintai firman Tuhan dan hukum-hukum Tuhan. Untuk mampu menjalankan nilai-nilai Kristen, maka tujuan pembelajara etika Kristen adalah: (1) mengembangkan karakter, (2) mengembangkan pelayanan bagi sesama manusia, (3) mengembangkan tanggung jawab individu. Estetika merupakan tujuan untuk memahami nilai-nilai keindahan realitas ciptaan Allah. Estetika yang tertinggi harus memberikan sikap positif, memberi dukungan, dan sesuatu yang memperkaya kehidupan manusia dalam kasih Tuhan. Kesenian memberikan kekuatan, kehormatan dan penghargaan dari sesuatu. Tujuan akhir estetika Kristen adalah karakter Kristen dalam mengembangkan seni dan keindahan sebagai pemberian dan anugerah yang Tuhan berikan. ${ }^{46}$

Ketika mempertanyakan nilai pada proses pendidikan, Dwayner Huebner mengatakan ada lima kategori nilai yang secara umum memandu praktik pendidikan dalam berbagai konteks: Pertama, nilai teknis menekankan pada pentingnya kontrol dan efisiensi dalam pendidikan. Nilai ini menekankan rasionalitasasi dari tujuan akhir, yang menggunakan pendekatan mode ekonomi dan berusaha memobilisasi materi dan sumber daya manusia untuk mendapatkan hasil yang diinginkan. Kedua, nilai politik mempertanyakan kekuatan yang biasanya tersembunyi dalam proses pendidikan. Pendidik mempunyai posisi yang berkuasa dan bisa mengendalikan orang lain dan bisa memengaruhi mereka dalam berbagai cara. Para peserta didik juga memiliki kekuatan untuk memengaruhi pendidik dan orang lain. Peserta didik dapat dilihat sebagai agen perubahan yang potensial atau aktual dalam gereja dan dunia. Ketiga, nilai ilmiah menekankan pada usaha pendidikan yang menghasilkan pengetahuan baru berbasis penelitian empiris. Dalam kategori ini, kesarjanaan dan penelitian sangat ditekankan sekaligus eksplorasi terhadap berbagai opsi dalam menemukan makna. Keempat, nilai estetik berfokus pada aktivitas-aktivitas yang mengandung makna simbolik atau estetik. Imajinasi, kreativitas, serta hal-hal yang berkaitan dengan aspek kehidupan yang tanpa akhir yang jelas termasuk dalam kategori ini. Kelima, nilai etis mempertimbangkan hal perjumpaan antar individu dengan pendidikan yang akan menghasilkan suatu kesadaran akan kehidupan bermoral. Dalam kategori ini, pendidik dipanggil untuk

\footnotetext{
${ }^{44}$ Pazmino, Fondasi Pendidikan Kristen, 138

${ }^{45}$ Paul Tillich, The Protestant Era, diterj. James I. Adams (Chicago:University of Chichago Press, 1948),

${ }^{46}$ Tung, Filsafat Pendidikan Kristen, 14
} 
memengaruhi peserta didik untuk hidup bertanggung jawab (kemampuan merespons) dalam berbagai area kehidupan. ${ }^{47}$

Keenam, nilai rohani yang menyangkut kepedulian untuk membebaskan seseorang dari kuasa dosa untuk hidup benar dan adil di hadapan Allah sebagai anak adopsi-Nya. Kategori ini menekankan pemahaman dan kehidupan yang dijalani sesuai dengan firman Tuhan dan pada saat yang bersamaan mendorong lahirnya perasaan heran, kagum, dan menyembah dalam seluru aspek kehidupan. Nilai rohani merupakan nilai yang paling tinggi dalam kehidupan orang Kristen dan bagi pendidikan kristiani dan harus memengaruhi nilai-nilai lainnya. Menurut Huebner hierarki nilai dapat terlihat dalam gambar 2 berikut:

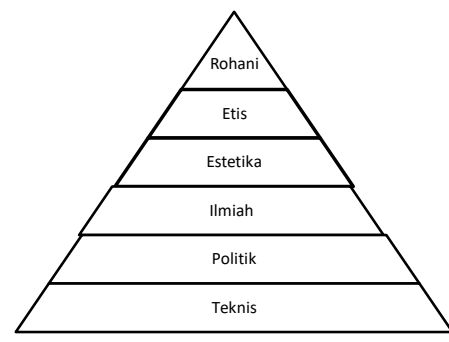

Gambar 2

Hirarki Nilai-nilai Menurut Dwayne Huebner

Menurut Huebner apabila nilai-nilai tersebut telah direformasi atau terbarukan secara rohani oleh kuasa Roh Kudus, maka akan terlihat hirarki nilai-nilai dalam gambar:

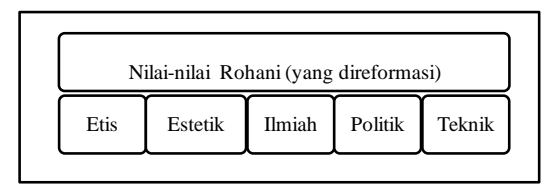

Gambar 3

Hirarki Nilai-nilai Rohani yang direformasikan Menurut Dwayne Huebner

Berdasarkan gambar di atas, nilai rohani ini akan meliputi seluruh area sebagai tempat untuk mempertimbangkan semua nilai pendidikan lainnya. Daripada memandanag nilai rohani sebagai kategori nilai keenam seharusnya nilai rohani memengaruhi atau mereformasi semua kategori nilai lainnya dengan caranya masingmasing. Pertama, nilai teknis yang menekankan kontrol dan efisiensi, bisa direformasi atau diperbaharui dengan menekankan penatalayanan dari sumber-sumber yang Allah berikan. Kehidupan digambarkan dan nilai-nilai yang dikomunikasikan dalam pendidikan bisa dilihat dalam hubungannya dengan keteraturan ciptaan Allah, yang mencerminkan keharmonisan, pemeliharaan dan kemahakuasaan Allah. Kedua, nilai politikyang menekankan kekuasaan dan legitimasi dari kuasa tersebut, bisa direformasi dalam pendidikan dengan cara menghargai semua usaha yang membebaskan dan memampukan orang lain. Hal ini terjadi saat setiap orang merendahkan diri di hadapan

\footnotetext{
${ }^{47}$ Dwayne Huebner, "Curriculum Languenge and Clasroom Meanings", dalam Curriculum Theorizing: The Reconceptualists, ed.William Pinar (Berkeley: McCuttcham, 1975), 215-218
} 
Allah dan melalui penebusan Yesus Kristus dapat menjadi alat-Nya untuk membawa transformasi yang kuat dalam masyarakat. Menjadi garam dan terang di dunia dan menjadi kuasa kebangkitan Yesus Kristus setiap hari dalam kehidupan personal dan sosial merupakan fokus dari nilai rohani dalam pendidikan (Mat.5:13-16; Flp. 3;10). Ada kuasa dalam pelayanan pendamaian, ada kuasa dalam menunjukkan teladan kasih dan pelayanan kepada orang lain, dan ada kuasa dalam menaati kehendak Allah, yang melampaui kekuatan manusia. Nilai politik ini berkaitan dengan tugas profetik gereja.

Ketiga, nilai ilmiah dengan fokus pada pengetahuan empiris, bisa direformasi dengan cara berfokus pada pengenalan akan Allah sebagai dasar untuk mengenal ciptaan-Nya dengan lebih baik. Tantangan bagi semua penelitian ilmiah adalah "menawan segala pikiran dan menaklukkannya kepada Kristus" (2 Kor. 10:5), melihat Dia sebagai segala harta hikmat dan pengetahuan (Kol. 2:2-3). Hal ini akan menjadi perspektif esensial untuk mengintegrasikan penemuan-penemuan dari semua disiplin ilmu. Tantangannya adalah memiliki pikiran Kristus melalui Kitab Suci dan pimpinan Roh Kudus, ketika seorang berhubungan dengan dunia yang natural dan supernatural.

Keempat, nilai estetika menekankan kebebasan, kreativitas dan keindahan. Kategori ini bisa direformasi dalam pendidikan dengan cara menekankan penyingkapan dari keindahan Kristus sebagaimana dinyatakan lewat ciptaan dan ekspresi serta potensi kreatif manusia. Manusia bisa memuliakan Allah lewat semua karya seni dan kerajinan tangan yang kreatif dan menyaksikan keindahan-Nya dalam kehidupan seharihari. Muncul kebutuhan dalam pendidikan untuk memampukan manusia agar dapat menunjukkan gambar kebebasan yang diberikan Allah dalam struktur dan ciptaan-Nya dengan baik lagi. Dan kelima, nilai etis bisa direformasi dalam pendidikan dengan cara mendorong orang-orang untuk mempertimbangkan dan mengaktualisasikan tindakan yang bertanggung jawab yaitu dalam hubungannya denga Tuhan, lalu dalam hubungannya dengan ciptaan, sesama, dan diri sendiri. Hal ini sangat berhubungan dengan gaya hidup orang Kristen dan keputusan etis dalam semua area kehidupan manusia. Pendidikan Kristen ditantang untuk memenuhi suatu panggilan hidup berintegritas dalam mengatasi masalah kontradiksi hidup akibat dosa pribadi dan sosial. Dan tantangan seperti ini harus juga diperhadapkan kepada peserta didik dalam proses pendidikan sehingga mereka bisa menghadapi dan mengatasinya dengan berpatokan pada nilai-nilai kehidupan kristiani sesuai firman Tuhan.

Apabila menjadi fokus pendidik Kristen, maka kelima nilai kebajikan kristiani akan berfungsi untuk memandu pengajaran yang mengikuti model integrasi yang dihasilkan dari tindakan mempertimbangkan fondasi-fondasi yang alkitabiah. Masing-masing kebajikan itu berhubungan dengan lima tugas pendidikan gerejawi dan karunia-karunia Roh Kudus bagi umat-Nya di dunia. Kelima tugas gerejawi itu adalah memberitakan Injil, membentuk komunitas, melayani, membela dan menyembah. Lima kebajikan yang berkaitan dengan kelima tugas gerejawi tersebut adalah kebenaran, kasih, iman, harapan dan sukacita. Terkait dengan masing-masing kebajikan itu ada suatu panggilan bagi para pendidik untuk mempertimbangkan evaluasi atau nilai-nilai dari proses belajar mengajar mereka. Pazmino mendeskripsikan dengan mengajukan pasanganpasangan dari kebajikan kristiani sebagai dasar evaluasi nilai-nilai kristiani, yaitu: kebenaran-suatu panggilan untuk integritas, kasih-suatu panggilan untuk pedul, imansuatu panggilan untuk bertindak, harapan-suatu panggilan untuk berani, dan sukacitasuatu panggilan untuk merayakan. ${ }^{48}$

Berkaitan dengan pengembangan kurikulum pendidikan Kristen. Tentu aspek aksiologi perlu dipertimbangkan sehingga kita dapat merumuskan dan mewujukan isi kurikulum yang benar-benar dapat sesuai dengan pengajaran Alkitab. Nilai-nilai

\footnotetext{
${ }^{48}$ Robert W. Pazmino, Basic of Teaching for Christian: Preparation, Instruction and Evaluation (Eugene: OR:Wipf \& Stock, 2002), 75-99
} 
kristiani yang termuat dalam Alkitab perlu dikaji dan disusun sedemikian rupa sehingga dapat diajarkan di ruang-ruang belajar sesuai dengan tingkat usia dari para peserta didik.

\section{Kesimpulan}

Lembaga pendidikan Kristen yang dikelolah dan Pendidikan Agama Kristen yang diajarkan di sekolah-sekolah termasuk di dalam gereja, tidak terlepas dari permasalahan-permasalahan filsafat seperti yang telah dibahas dari sistematika filsafat yaitu metafisika, epistemologi dan aksiologi. Terkhususnya dalam pengembangan kurikulum pendidikan Kristen aspek metafisika yang bisa muncul dalam wujud core dan hidden kurikulum, dan aspek epistemologi dimana kesahihan dan validitas suatu kebenaran pengetahuan sangat ditekankan dalam pendidikan dan aspek aksiologi yang menekankan pentingnya etika dan estetika dalam suatu pendidikan, maka ketiga hal ini sangat perlu dipertimbangkan dan menjadi perhatian serius para pelaku pendidikan yang sedang mengelolah lembaga pendidikan baik secara umum maupun secara khusus berbasiskan keagamaan.

\section{Referensi}

Cober Kenneth L., Shaping the Church's Education Ministry: A Manual for the Board of Christian Education (Valey Forge: Judson Press, 1971.

Cremin Lawrence A., Public Education (New York: Basic Books, 1976.

Hisaini Ardian, Filsafat Ilmu: Perspektif Barat dan Islam (Jakarta: Gema Insani, 2013.

Huebner Dwayne, "Curriculum Languenge and Clasroom Meanings", dalam Curriculum Theorizing: The Reconceptualists, ed.William Pinar (Berkeley: McCuttcham, 1975.

Kattsoff Louis O., Pengantar Filsafat. Yogya: Tiara Wacana, 2004.

Knight George R., Philosophy and Education An Introduction In Christian Perspektive ( Berrien Springs, MI: Andrews University Press, 1980.

Paker Parker J., To Know as We Are Known: A Spritually of Education (San Fransisco:Harper \&Row, 1983.

Pazmino Robert W., Basic of Teaching for Christian: Preparation, Instruction and Evaluation (Eugene: OR:Wipf \& Stock, 2002.

Fondasi Pendidikan Kristen (Jakarta: BPK. Gunung Mulia, 2012.

Sadulloh Uyoh, Pengantar Filsafat Pendidikan. Bandung: Alfabeta, 2008.

Simanjuntak Jonihot, Filsafat Pendidikan dan Pendidikan Kristen (Yogyakarta: Andi, 2013.

Suriasumantri Jujun S., Filsafat IImu Sebuah Pengantar Populer. Jakarta: Pustaka Sinar Harapan, 2009.

Spradley Joseph, "A Christian View of the Physical World" dalam The Making of a Christian Mind: A Chistian World View and the Academic Enterprice, ed.Arthur F. Holmes (Downers Grove II: InterVarsity,1985.

Tillich Paul, The Protestant Era, diterj. James I. Adams (Chicago:University of Chichago Press, 1948.

Tung Khoe Yao, Filsafat Pendidikan Kristen (Yogyakarta: Andi, 2013.

Vieth Paul H., Objektives in Religious Education (New York:Harper\& Bross, 1930. 